\title{
Characterization of structural proteins of hirame rhabdovirus, HRV
}

\author{
Toyohiko Nishizawa ${ }^{1}$, Mamoru Yoshimizu ${ }^{1}$, James Winton ${ }^{2}$, Winfried Ahne ${ }^{3}$, \\ Takahisa Kimura ${ }^{1}$ \\ ${ }^{1}$ Laboratory of Microbiology, Faculty of Fisheries, Hokkaido University, Minato, Hakodate, Hokkaido 041, Japan \\ ${ }^{2}$ National Fisheries Research Center, Bldg. 204, Naval Station, Seattle, Washington 98115 , USA \\ ${ }^{3}$ Institute for Zoology and Hydrobiology, University of Munich, Kaulbachstraße 37, W-8000 München 22, Germany
}

\begin{abstract}
Structural proteins of hirame rhabdovirus (HRV) were analyzed by SDS-polyacrylamide gel electrophoresis, western blotting, 2-dimensional gel electrophoresis, and Triton X-100 treatment. Purified HRV virions were composed of: polymerase (L), glycoprotein (G), nucleoprotein (N), and 2 matrix proteins (M1 and $M 2$ ). Based upon their relative mobilities, the estimated molecular weights of the proteins were: L, $156 \mathrm{KDa} ; \mathrm{G}, 68 \mathrm{KDa}$;, $46.4 \mathrm{KDa}$; M1, $26.4 \mathrm{KDa}$; and M2, 19.9 KDa. The electrophoretic pattern formed by the structural proteins of HRV was clearly different from that formed by pike fry rhabdovirus, spring viremia of carp virus, eel virus of America, and eel virus European $X$ which belong to the Vesiculovirus genus; however, it resembled the pattern formed by structural proteins of viral hemorrhagic septicemia virus (VHSV) and infectious hematopoietic necrosis virus (IHNV) which are members of the Lyssavirus genus. Among HRV, IHNV, and VHSV, differences were observed in the relative mobilities of the $G, N, M 1$, and $M 2$ proteins. Western blot analysis revealed that the $G, N$, and M2 proteins of HRV shared antigenic determinants with IHNV and VHSV, but not with any of the 4 fish vesiculoviruses tested. Cross-reactions between the M1 proteins of HRV, IHNV, or VHSV were not detected in this assay. Two-dimensional gel electrophoresis was used to show that HRV differed from IHNV or VHSV in the isoelectric point (pI) of the M1 and M2 proteins. In this system, 2 forms of the M1 protein of HRV and IHNV were observed. These subspecies of M1 had the same relative mobility but different $\mathrm{pI}$ values. Treatment of purified virions with $2 \%$ Triton $\mathrm{X}-100$ in Tris buffer containing $\mathrm{NaCl}$ removed the $\mathrm{G}, \mathrm{M} 1$, and $\mathrm{M} 2$ proteins of IHNV, but HRV virions were more stable under these conditions.
\end{abstract}

\section{INTRODUCTION}

Hirame rhabdovirus (HRV) was first isolated from moribund hirame (Japanese flounder Paralichthys olivaceus) in Hyogo Prefecture, Japan (Gorie et al. 1985, Kimura et al. 1986, Kimura et al. 1989). Subsequently, HRV was isolated from hirame, ayu Plecoglossus altivelis, and black seabream Milio macrocephalus cultured in Hyogo, Kagawa, Hokkaido, and Mie Prefectures (Yoshimizu et al. 1987), and from mebaru Sebastes inermis imported from Korea to Kagawa Prefecture (Sano \& Fukuda 1987). Although HRV is a member of the Rhabdoviridae based upon biochemical and biophysical characteristics, it can be distinguished from other fish rhabdoviruses by serum neutralization tests (Kimura et al. 1986).

Two major genera of the family Rhabdoviridae, Vesiculovirus and Lyssavirus, have been described (Mat- thews 1982, Wagner 1987). Vesicular stomatitis virus (VSV), the prototype Vesiculovirus, has a virion composed of 5 structural proteins: polymerase (L), glycoprotein (G), nucleocapsid protein (N), a phosphoprotein ( $P$, formerly Ns), and matrix protein (M) (Kang \& Prevec 1971, Knipe et al. 1975, Wagner 1987). The virion of rabies virus, the prototype Lyssavirus, is composed of $\mathrm{L}$, G, N, and 2 matrix proteins $\mathrm{M} 1$ and M2 (Madore \& England 1977, Wagner 1987). Among the rhabdoviruses of fish, pike fry rhabdovirus (PFR), spring viremia of carp virus (SVCV), eel virus European $\mathrm{X}$ (EVEX), and eel virus of America (EVA) have been shown to be vesiculoviruses while infectious hematopoietic necrosis virus (IHNV) and viral hemorrhagic septicemia virus (VHSV) are lyssaviruses (Hill et al 1975, Lenoir \& de Kinkelin 1975, de Kinkelin et al 1980, Hill et al. 1980, Leong et al. 1981, Hsu et al. 1985 . Kanai et al. 1985, Lorenzen et al. 1988). 
We used SDS-polyacrylamide gel electrophoresis (SDS-PAGE; Laemmli 1970) to analyze the 5 structural proteins of hirame rhabdovirus and compared their relative mobilities with those of other fish rhabdoviruses. A western blot analysis (Towbin et al. 1979) was used to examine the antigenic relatedness of these structural proteins. Because HRV was similar to IHNV and VHSV by SDS-PAGE, we used 2-dimensional electrophoresis (O'Farrell 1975) to determine the isoelectric points of the structural proteins of these 3 viruses. Finally, we tested the stability of IHNV and HRV in the presence of Triton X-100 which has been shown to selectively remove structural proteins from the IHNV virion (McAllister \& Wagner 1975). The results from our study indicate that HRV is a member of the Lyssavirus genus and, while related to both IHNV and VHSV, could be clearly distinguished from them by the methods used in this study.

\section{MATERIALS AND METHODS}

Cell lines and viruses. Epithelioma papulosum cyprini (EPC; Fijan et al, 1983) and fathead minnow (FHM; Gravell \& Malsberger 1965) cell lines were used. The cells were grown at $15^{\circ} \mathrm{C}$ in Eagle's minimum essential medium (MEM; Gibco) supplemented with 10\% fetal bovine serum (FBS; Flow Laboratories), $100 \mathrm{IU} \mathrm{ml} \mathrm{ml}^{-1}$ penicillin (Sigma), and $100 \mu \mathrm{g} \mathrm{ml} \mathrm{m}^{-1}$ streptomycin (Sigma).

Isolates of VHSV (strain F1), IHNV (isolated from rainbow trout, cultus laka, Canada), PFR, SVCV, EVEX, and EVA were used as reference viruses. These were kindly provided by: Dr P. V. Jørgensen, State Serum Laboratory, Århus, Demark (VHSV), Dr B. J. Hill, Fish Disease Laboratory, Ministry of Agriculture, Fisheries and Food, UK (IHNV and SVCV), Dr P. de Kinkelin, Institut National de la Recherche Agronomique, France (PFR), and Dr T. Sano, Laboratory of Fish Pathology, Tokyo University of Fisheries, Japan (EVEX and EVA).

Purification of viruses. Monolayers of FHM cells grown in $75 \mathrm{~cm}^{2}$ plastic tissue culture flasks (Falcon) were infected with virus at a low multiplicity of infection $(0.01$ to 0.001$)$ and incubated at $15^{\circ} \mathrm{C}$. After $7 \mathrm{~d}$, or when monolayers showed complete lysis, the culture fluid was collected and clarified by centrifugation $(4000 \times g, 10 \mathrm{~min})$. Virus in the supernatant was precipitated by addition of $7.0 \%(\mathrm{w} / \mathrm{v})$ polyethylene glycol 6000 (PEG) and $2.3 \%(\mathrm{w} / \mathrm{v}) \mathrm{NaCl}$. The mixture was stirred overnight at $4{ }^{\circ} \mathrm{C}$. After low-speed centrifugation $(3000 \times \mathrm{g}, 30 \mathrm{~min})$, the pellet was resuspended in $1 / 10$ volume of STE buffer $(0.02 \mathrm{M}$ Tris- $\mathrm{HCl}, 0.1 \mathrm{M}$ $\mathrm{NaCl}, 1 \mathrm{mM}$ EDTA, pH 7.4) and the mixture centrifuged $(4000 \times g, 10 \mathrm{~min})$ to remove PEG. Viral particles in the supernatant were collected by centrifugation $(18500 \times g, 150 \mathrm{~min})$. The pellet was resuspended in STE buffer and the virus centrifuged $(80000 \times \mathrm{g}, 90$ min) through a discontinuous gradient composed of $50 \%, 35 \%$, and $20 \%$ sucrose $(w / w)$ in STE. The virus band was harvested from the $20 / 35 \%$ interface and pelleted by centrifugation $(150000 \times g, 60 \mathrm{~min})$. The pellet was resuspended in STE buffer and the virions centrifuged $(43000 \times \mathrm{g}, 30 \mathrm{~min})$, through a continuous gradient of 5 to $30 \%$ sucrose $(\mathrm{w} / \mathrm{w})$ in STE. The band of purified virus was removed and collected by centrifugation $(150000 \times g, 60 \mathrm{~min})$. Finally, the pellet was resuspended in STE and stored at $-80^{\circ} \mathrm{C}$ until used.

SDS-polyacrylamide gel electrophoresis. Purified virus was mixed with an equal volume of denaturing buffer (166 mM Tris- $\mathrm{HCl}, \mathrm{pH} 6.8 ; 5.3 \%$ SDS; $13 \% 2$ mercaptoethanol) and heated $\left(100^{\circ} \mathrm{C}, 3 \mathrm{~min}\right)$. After cooling, a tracking dye and glycerol mixture $10.5 \%$ Bromphenol Blue, $70 \%$ glycerol, $0.0625 \mathrm{M}$ Tris- $\mathrm{HCl}$, $\mathrm{pH} \mathrm{6.8)}$ was added and the samples stored at $-20^{\circ} \mathrm{C}$.

SDS-PAGE analysis of virion proteins was performed using $10 \%$ acrylamide separating gels overlayed with $2.5 \%$ acrylamide stacking gels. The samples were electrophoresed under constant current of $10 \mathrm{~mA}$ for $1 \mathrm{~h}$ through the stacking gel and then $20 \mathrm{~mA}$ for $2 \mathrm{~h}$ in the slab gel. After electrophoretic separation, the gels were stained with silver nitrate and the relative mobilities of the proteins determined by comparison with internal standard proteins of known molecular weight (Sigma).

Western blot analysis. Proteins separated by SDSPAGE were transferred to nitrocellulose (NC) membranes $(0.45 \mu \mathrm{m}$, Advantec) and reacted with antiserum using a modification of the method of Towbin et al. (1979). The proteins were transferred to NC at constant current of $180 \mathrm{~mA}$ for $90 \mathrm{~min}$ in blotting buffer $(50 \mathrm{mM}$ Tris- $\mathrm{HCl}_{1} 192 \mathrm{mM}$ glycine, $\mathrm{pH} 8.3$ ) and the membrane blocked using $2 \%(\mathrm{w} / \mathrm{v})$ skim milk in TBS buffer $10.9 \%$ $\mathrm{NaCl}$ in $20 \mathrm{mM}$ Tris, $\mathrm{pH} 8.0$ ). The membranes were washed for $20 \mathrm{~min}$ in TBS then treated for $2 \mathrm{~h}$ with antiserum to HRV or IHNV diluted in TBS containing $0.2 \%(\mathrm{v} / \mathrm{v})$ bovine serum albumin (BSA). After washing $20 \mathrm{~min}$ in TBS, the membranes were treated for $1 \mathrm{~h}$ with peroxidase-conjugated swine anti-rabbit IgG (Dako) in TBS containing $0.2 \%$ BSA. The membranes were again washed for $20 \mathrm{~min}$ in TBS and stained by addition of $0.5 \mathrm{mg} \mathrm{ml}^{-1} 3,3^{\prime}$-diaminobenzidine tetrahydrochloride and $0.05 \%(v / v) \mathrm{H}_{2} \mathrm{O}_{2}$ in TBS buffer.

Two-dimensional electrophoresis. Two-dimensional gel electrophoresis (2DGE) was performed using a modification of a commercial protocol (Pharmacia). For the first dimension, isoelectric focusing (IEF) tube gels $(180 \times 2.7 \mathrm{~mm})$ were prepared with $4 \%$ acrylamide, $2 \%$ pharmalyte pH 3-10 (Pharmacia), $8 \mathrm{M}$ urea, and $2 \%$ NP-40. After adding overlay solution of $2 \%$ phar- 
malyte, $8 \mathrm{M}$ urea, and $2 \% \mathrm{NP}-40$, the tube gels were placed between a cathode buffer $(0.02 \mathrm{M} \mathrm{NaOH})$ and anode buffer $\left(0.01 \mathrm{M} \mathrm{H}_{3} \mathrm{PO}_{4}\right)$ and prefocused at 300 to $400 \mathrm{~V}$ for $30 \mathrm{~min}$.

Samples for IEF were prepared by adding 2 volumes of purified virus to 3 volumes of an SDS/urea solution (5\% SDS, $9 \mathrm{M}$ urea, $2 \%$ pharmalyte, $5 \% 2$-mercaptoethanol). After incubation at room temperature for $15 \mathrm{~min}, 3$ volumes of NP-40/urea solution ( $4 \%$ NP-40, $9 \mathrm{M}$ urea, $2 \%$ pharmalyte, $5 \%$ 2-mercaptoethanol) were added and the mixture incubated for another 15 min. The samples were placed on top of the IEF tube gels and the proteins separated by electrophoresis at $500 \mathrm{~V}$ for $16 \mathrm{~h}$.

After IEF, a control gel was sliced into $1 \mathrm{~cm}$ sections which were transferred to $1 \mathrm{ml}$ portions of distilled water for $5 \mathrm{~h}$ incubation at room temperature when the $\mathrm{pH}$ of each fraction was measured. Gels containing samples for 2DGE were removed from the tubes, incubated for $30 \mathrm{~min}$ in equilibration buffer $(0.0625 \mathrm{M}$ Tris$\mathrm{HCl} \mathrm{pH} 6.8,2 \%$ SDS, 5\% 2-mercaptoethanol), and fixed to tops of $2 \%$ polyacrylamide gels with melted $2 \%$ agarose in equilibrium buffer. Second dimension electrophoresis conditions and gels were the same as for SDS-PAGE.

Treatment of virions with Triton X-100. Purified virus was suspended in $10 \mathrm{mM}$ Tris buffer ( $\mathrm{pH}$ 7.4) with or without $2 \%$ Triton X-100 containing different concentrations of $\mathrm{NaCl}(0,0.43$, and $0.72 \mathrm{M})$. After incubation at $25^{\circ} \mathrm{C}$ for $60 \mathrm{~min}$, the treated virions were pelleted by centrifugation $(150000 \times g, 60 \mathrm{~min})$ and the viral pellet resuspended in SDS-PAGE sample buffer. Preparation of SDS-PAGE gels and electrophoresis conditions were the same as described.

\section{RESULTS}

\section{Structural proteins of $\mathrm{HRV}$}

The results of SDS-PAGE analysis of the structural proteins of HRV, IHNV, VHSV, PFR, SVCV, EVEX, and EVA are shown in Fig. 1. The patterns of HRV,

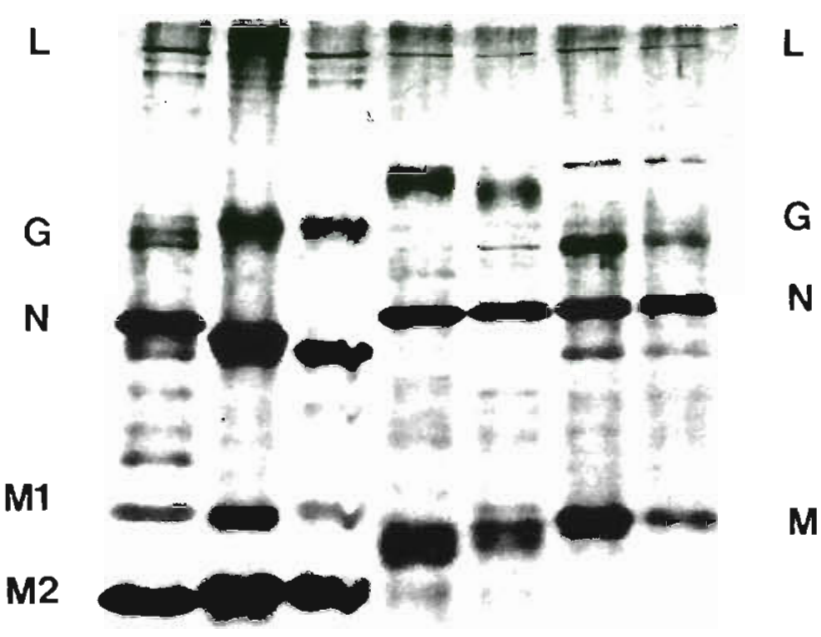

\section{$\begin{array}{lllllll}1 & 2 & 3 & 4 & 5 & 6 & 7\end{array}$}

Fig. 1. Analysis of the structural proteins of hirame rhabdovirus (HRV, lane 1); viral hemorrhagic septicemia virus (VHSV, lane 2); infectious hematopoietic necrosis virus (IHNV, lane 3); pike fry rhabdovirus (PFR, lane 4); spring viremia of carp virus (SVCV, lane 5); eel virus European $\mathrm{X}$ (EVEX, lane 6); and eel virus of America (EVA, lane 7) using a $10 \%$ polyacrylamide gel stained with silver nitrate. The polymerase (L), glycoporotein (G), nucleoporotein (N), and matrix proteins (M1, M2) of the 3 lyssaviruses, HRV, VHSV, and IHNV, form patterns different from the 4 vesiculoviruses, PFR, SVCV, EVEX, and EVA. The phosphoprotein ( $\mathrm{P}$, formerly Ns) of PFR, SVCV, EVEX, and EVA cannot be easily seen by SDS-PAGE

IHNV, and VHSV were similar to each other, but differed from those of PFR, SVCV, EVEX, and EVA. Differences were observed between HRV, IHNV, and VHSV in the relative mobilities of the G, N, M1 and M2 proteins. The HRV virion contained 5 structural proteins with estimated molecular weights of $156,68,46.4$, 26.4, and $19.9 \mathrm{KDa}$. The $\mathrm{M} 2$ protein of HRV was smaller, while the $N$ protein was larger, than the corresponding proteins of IHNV or VHSV (Table 1). The HRV M1 protein was larger than that of VHSV but about the same as that of IHNV. These results showed that HRV was a typical member of the Lyssavirus genus, but differing from IHNV and VHSV.

Table 1. Molecular weight estimates in kilodaltons of the structural proteins of 7 fish rhabdoviruses based upon relative mobility in SDS-polyacrylamide gels as shown in Fig. 1. The 3 lyssaviruses, HRV, IHNV, and VHSV, could be differentiated based upon relative mobilities of the $N$ and $M 1$ proteins

\begin{tabular}{|cccccccc|}
\hline Protein & HRV & IHNV & VHSV & PFR & SVCV & EVEX & EVA \\
\hline L & 156 & 156 & 156 & 156 & 156 & 156 & 156 \\
G & 68.0 & 67.8 & 68.5 & 76.8 & 76.0 & 67.2 & 67.2 \\
N & 46.4 & 42.0 & 43.5 & 49.1 & 49.1 & 48.7 & 48.7 \\
M1 & 26.4 & 26.4 & 24.8 & - & - & - & 23.7 \\
M & - & - & - & 24.0 & - & - & - \\
M2 & 19.9 & 20.6 & 20.6 & - & & & - \\
\hline
\end{tabular}


(A)

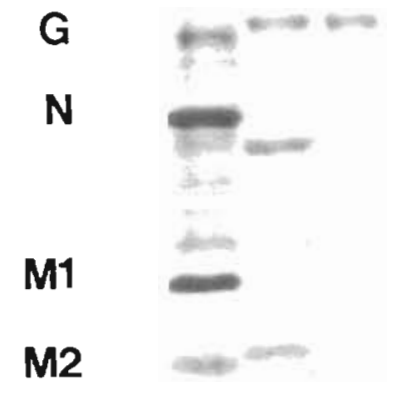

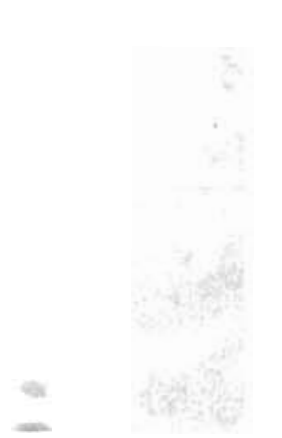

$\begin{array}{lllllll}1 & 2 & 3 & 4 & 5 & 6 & 7\end{array}$
(B)

G

N

M1

M2

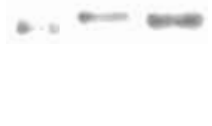

$\begin{array}{lllllll}1 & 2 & 3 & 4 & 5 & 6 & 7\end{array}$

Fig. 2 Western blot analysis of the structural proteins of hirame rhabdovirus (HRV, lane 1); infectious hematopoietic necrosis virus (IHNV, lane 2); viral hemorrhagic septicemia virus (VHSV, lane 3); pike fry rhabdovirus (PFR, lane 4); spring viremia of carp virus (SVCV, lane 5); eel virus European X (EVEX, lane 6); and eel virus of America (EVA, lane 7). Proteins were transferred to nitrocellulose membranes and reacted with antiserum against HRV or IHNV With the HRV antiserum (left), cross-reactions were seen with the glycoprotein (G) of IHNV and VHSV and with the nucleoporotein (N) and matrix protein 2 (M2) of IHNV. Similarly, using antiserum against IHNV (right), cross-reactions were observed with the G and M2 proteins of HRV and VHSV and with the $\mathrm{N}$ protein of HRV. No cross-reactions were observed with matrix protein 1 (M1) or with any proteins of PFR, SVCV, EVEX, and EVA

\section{Western blot analysis}

Antisera against HRV and IHNV showed extensive cross-reactions with structural proteins of the 3 fish lyssaviruses but not with the proteins of the 4 fish vesiculoviruses tested (Fig. 2). While staining was strongest between each antiserum and the homologous virus, anti-HRV serum showed significant reactions with the G, N, and M2 proteins of IHNV and the G proteins of VHSV. Conversely, the antiserum against IHNV cross-reacted strongly with the $G$ proteins of HRV and VHSV and, to a lesser extent, with the $\mathrm{N}$ and M2 proteins. The M1 protein of HRV and IHNV did not cross-react to any detectable extent. These results sug-

Table 2. Isoelectric points (pl) of the structural proteins of hirame rhabdovirus (HRV), infectious hematopoietic necrosis virus (IHNV), and viral hemorrhagic septicemia virus (VHSV). Two pI values are given for the M1 proteins of HRV and IHNV where 2-dimensional gel electrophoresis was able to resolve 2 species of this protein differing in $\mathrm{pI}$

\begin{tabular}{|lccc|}
\hline & HRV & IHNV & VHSV \\
\hline Polymerase (L) & $6.2-6.7$ & $6.0-7.0$ & $6.0-6.8$ \\
Glycoprotein (G) & $7.1-7.3$ & $6.9-7.1$ & nd \\
Nucleoprotein (N) & $5.9-6.2$ & $5.9-6.2$ & $5.9-6.2$ \\
Matrix protein 1 (M1) & 7.3 & 7.8 & 8.5 \\
& 7.4 & 8.0 & - \\
Matrix protein 2 (M2) & $9.1-9.3$ & $9.6-9.89$ & 9.8 \\
\multicolumn{1}{c}{ nd: not detected } & & & \\
\cline { 1 - 2 } & & & \\
\hline
\end{tabular}

gest that HRV, IHNV, and VHSV share a significant number of antigenic determinants with each other, but not with any of the fish vesiculoviruses.

\section{Two-dimensional electrophoresis of HRV, IHNV, and VHSV}

The results of the 2-dimensional gel electrophoresis of HRV, IHNV, and VHSV are shown in Table 2. In the IEF dimension, the $\mathrm{pH}$ gradient was linear from $\mathrm{pH} 5.0$ to 11.0. Comparing HRV, IHNV, and VHSV, the pI values of the $L, G$, and N proteins were similar, but the pI values of the $M 1$ and $M 2$ proteins were quite different and could be used to distinguish HRV from IHNV and VHSV.

The 2DEF gels revealed the M1 proteins of both HRV and IHNV migrated to form 2 separate spots which had the same molecular weight but different pls, the M1 protein of VHSV produced only one spot in the 2dimensional electrophoresis gel.

\section{Treatment of viruses with Triton $\mathrm{X}-100$}

We tested the effect of Triton X-100 on the stability of the virions of HRV and IHNV (Fig. 3). The G protein of IHNV was readily removed by Triton X-100 and both the $\mathrm{M} 1$ and $\mathrm{M} 2$ proteins were removed by Triton $\mathrm{X}-100$ containing $0.43 \mathrm{M}$ or $0.72 \mathrm{M} \mathrm{NaCl}$. However, the structural proteins of HRV were much more stable under the same conditions. 
Fig 3. Polyacrylamide gel electrophoresis of the structural proteins of hirame rhabdovirus (HRV) and infectious hematopoietic necrosis virus (IHNV) following treatment with $2 \%$ Triton $\mathrm{X}-100$ at selected salt concentrations. Purified viruses were suspended in $10 \mathrm{mM}$ Tris buffer (lane 1) or treated with: $2 \%$ Triton X-100 (lane 2), $2 \%$ Triton X-100 with $0.43 \mathrm{M} \mathrm{NaCl}$ (lane 3), or $2 \%$ Triton $\mathrm{X}-100$ with $0.72 \mathrm{M} \mathrm{NaCl}$ (lane 4)

\section{DISCUSSION}

The HRV virion was composed of 5 structural proteins with estimated molecular weights of $156,68,46.4$, 26.4 , and $19.9 \mathrm{KDa}$. The SDS-PAGE pattern formed by the proteins of HRV was clearly different from that of the vesiculoviruses PFR, SVCV, EVEX, and EVA, but similar to that of the fish lyssaviruses IHNV and VHSV. However, HRV could be distinguished from IHNV and VHSV by the molecular weights of the G, N, M1, and M2 proteins. Hsu et al. (1986) examined 71 isolates of IHNV from North America by SDS-PAGE and described 5 electropherotypes based upon differences in relative mobilities of the $G$ and $N$ proteins. In our SDS-PAGE gels, the estimated molecular weight of the $N$ protein of HRV fell outside of the range of molecular weights reported for those strains of IHNV. Yoshimizu et al. (1987) showed that 11 isolates of HRV from fish in Japan had the same SDS-PAGE patterns.

Western blot analysis revealed significant antigenic relatedness between the $G, N$, and $M 2$ proteins of HRV, IHN, and VHSV. While the extent of these crossreactions can be expected to vary depending upon the source of the antiserum, we did not detect any crossreaction in the M1 proteins of HRV and IHNV suggesting they are unique viruses. While the fish lyssaviruses appeared to share a large number of antigenic determinants, there was no antigenic relatedness with the fish vesiculoviruses indicating a greater evolutionary distance. Our results are analogous to those reported by Jørgensen et al. (1989) who performed a western blot analysis of the structural proteins of SCVC, PFR, and VHSV using antisera against SVCV and PFR. These antisera reacted specifically with the NS protein of the homologous virus, but showed cross-reactions
$\mathbf{L}$

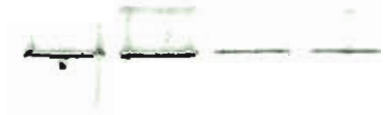

G

N

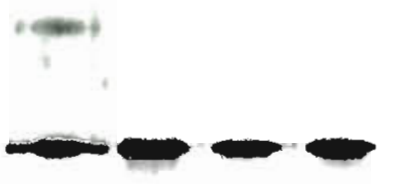

M1

M2

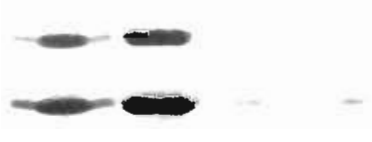

123

4

\section{HRV}

\section{IHNV}

between the $G$ and $N$ protein of SVCV and PFR. In addition, the PFR antiserum stained the $M$ proteins of both viruses. No cross-reaction was seen with any of the VHSV structural proteins.

Two-dimensional electrophoresis was used to compare the structural proteins of HRV, IHNV, and VHSV. The $\mathrm{pI}$ of the M2 protein of HRV was more acidic than that of IHNV and VHSV and could be used to distinguish HRV from IHNV or VHSV. The M1 protein of both HRV and IHNV formed 2 spots with different pI values. This may be due to differences in the degree of phosphorylation of the M1 protein of these viruses. McAllister \& Wagner (1975) determined both the $N$ and M1 protein of IHNV, but only the $\mathrm{N}$ porotein of VHSV was a phosphoprotein.

Triton X-100 treatment of the HRV, IHNV, and VHSV virions showed that the G protein of IHNV was easily removed by treatment with Triton $\mathrm{X}-100$ in low ionic strength buffer. In the presence of Triton X-100 and salt, the M1 and M2 proteins of IHNV were solubilized in addition to the $G$ protein. These results are consistent with the findings of McAllister \& Wagner (1975) and Lenoir \& de Kinkelin (1975). In contrast, the structural proteins of HRV were substantially more stable in the presence of Triton X-100 or Triton X-100 containing $\mathrm{NaCl}$. It is not clear why the virions of $\mathrm{HRV}$ were more stable than those of IHNV.

In this study, the structural proteins of HRV could be distinguished from IHNV and VHSV by differences in relative mobility in SDS-PAGE, lack of antigenic relatedness of the $\mathrm{M} 1$ protein and western blots, differing $\mathrm{pI}$ values of the $\mathrm{M} 1$ and $\mathrm{M} 2$ proteins, and the stability in the presence of Triton X-100. Taken together, these data indicate that HRV is a novel fish rhabdovirus. 
Acknowledgements. The authors thank Cindy Arakawa and Kevin Oshima of the National Fisheries Research Center, Seattle, for technical assistance with portions of this work.

\section{LITERATURE CITED}

De Kinkelin, P., Berre, M. B., Bernard, J. (1980). Viral hemorrhagic septicemia of rainbow trout: Selection of a thermoresistant virus variant and comparison of polypeptide synthesis with the wild-typevirus strain. J. Virol. 12: $652-658$

Fijan, N., Sulimanovic, D., Bearzotti, M., Muzinic, D., Zwillenberg, L. O., Chilmonczyk, S., Vautherot, J. F., de Kinkelin, P. (1983). Some properties of the epithelioma papulosum cyprini (EPC) cell line from carp (Cyprinus carpio). Ann Virol. (Inst. Pasteur) 134: 207-220

Gorie, S., Nakamoto, K., Katashima, K. (1985). Disease of cultured hirame (Japanese flounder) Paralichtys olivaceus I. Preliminary report on a disease of marine pen cultured flounder may be caused by viral infection. Bull. Hyogo. Pref. Fish Exp. Stn 23: 66-68

Gravell, M., Malsberger, R. G. (1965). A permanent cell line from the fathead minnow (Pimephales promelas). Ann. N.Y Acad. Sci. 126: 555-565

Hill, B. J., Underwood, B. O., Smale, C. J., Brown, F. (1975) Physicochemical and serological characterization of five rhabdoviruses infecting fish. J. gen. Virol. 27: 369-378

Hill, B. J., Willilams, R. F., Smale, C. J., Underwood, B. O., Brown, F. (1980). Physicochennical and serological characterization of two rhabdoviruses isolated from eels. Intervirol. 14: 208-212

Hsu, Y.-L., Engelking, H. M., Leong, J. C. (1985). Analysis of the quantity and synthesis of the virion proteins of infectious hematopoietic necrosis virus. Fish Pathol. 20: 331-338

Hsu, Y.-L., Engelking, M., Leong, J. C. (1986). Occurrence of different types of infectious hematopoietic necrosis virus in fish. Appl. environ. Microbiol. 52: 1353-1361

Jørgensen, P. E., Olesen, N. J., Ahne, W., Lorenzen, N. (1989). SVCV and PFR viruses: serological examination of 22 isolates indicates close relationship between the two fish rhabdoviruses. In: Ahne, W., Kurstak, E. (eds.) Viruses of lower vertebrates. Springer, Berlin, p. 349-366

Kanai, K., Fukuda, H., Sano, T (1985). Molecular variants of IHN virus strains in Japan and USA. Fish Pathol. 20: 71-72

Editorial responsibility: Managing Editor
Kang, C. Y., Prevec, L. (1971). Proteins of vesicular stomatitis virus. III. Intra-cellular synthesis and assembly of virusspecific proteins. Virol. 46: 678-690

Kimura, T., Yoshimizu, M., Gorie, S. (1986). A new rhabdovirus isolated in Japan from cultured hirame (Japanese flounder, Paralichthys olivaceus) and ayu (Plecoglossus altivelis). Dis. aquat. Org. 1: 209-217

Kimura, T., Yoshimizu, M., Oseko, N., Nishizawa, T. (1989). Rhabdovirus olivaceus (Hirame rhabdovirus). In: Ahne, W., Kurstak, E. (eds.) Viruses of lower vertebrates. Springer, Berlin, p. 388-395

Knipe, D., Rose, J. K, Lodish, H. F. (1975). Translation of individual species of vesicular stomatitis viral mRNA. J Virol. 4: 1004-1011

Laemmli, U. K. (1970). Cleavage of structural proteins during the assembly of the head of bacteriophage T4. Nature, Lond. 227: 680-685

Lenoir, G., de Kinkelin, P. (1975). Fish rhabdovinus: comparative study of protein structure. J. Virol. 16: 259-266

Leong, J. C., Hsu, Y.-L., Engelking, H. M., Mulcahy, D. (1981). Strains of infectious hematopoietic necrosis (IHN) virus may be identified by structural protein differences. Develop. Biol. Stand. 49: 43-55

Lorenzen, N., Olesen, N. J., Jørgensen, P. E. V. (1988). Production and characterization of monoclonal antibodies to four Egtved virus structural proteins. Dis. aquat. Org. 4: 35-42

Madore, H. P., England, J. M. (1977). Rabies virus protein synthesis in infection BHK-Cells. J. Virol. 4: 102-112

Matthews, R. E. F. (1982). Classification and nomenclature of viruses. Karger, Basel, p. 109-114

McAllister, P. E., Wagner, R. R. (1975). Structural proteins of two salmonid rhabdoviruses. J. Virol. 4: 733-738

O'Farrell, P. H. (1975). High resolution two-dimensional electrophoresis of proteins. J. biol. Chem. 250: 4007-4021

Sano, T., Fukuda, H. (1987). Principal microbial disease of mariculture in Japan. Aquaculture 67: 59-70

Towbin, H., Staehelin, T., Gordon, J. (1979). Electrophoretic transfer of protein from polyacrylamide gels to nitrocellulose sheets: procedure and some applications. Proc. natn. Acad. Sci. USA. 76: 4350-4354

Wagner, R. R. (ed.). (1987). The Rhabdoviruses. Plenum, New York

Yoshimizu, M., Nishizawa, T., Oseko, N., Kimura, T (1987). Rhabdovirus disease of hirame (Japanese flounder). Proceedings of the symposium 'Disease problem of the $f_{r y}$ stage of sea water fish.' Fish Pathol. 22: 54-55 (in Japanese)

Manuscript first received: June 11, 1990

Revised version accepted: January 7, 1991 